\title{
Kernos
}

Revue internationale et pluridisciplinaire de religion grecque antique

$25 \mid 2012$

Varia

\section{Burkhard FEHR, Becoming Good Democrats and Wives. Civic Education and Female Socialization on the Parthenon Frieze}

Joannis Mylonopoulos

\section{OpenEdition}

\section{Journals}

Electronic version

URL: http://journals.openedition.org/kernos/2055

DOI: 10.4000/kernos.2055

ISSN: 2034-7871

\section{Publisher}

Centre international d'étude de la religion grecque antique

\section{Printed version}

Date of publication: 26 October 2012

Number of pages: 347-352

ISSN: 0776-3824

\section{Electronic reference}

Joannis Mylonopoulos, «Burkhard FeHR, Becoming Good Democrats and Wives. Civic Education and Female Socialization on the Parthenon Frieze », Kernos [Online], 25| 2012, Online since 01 October 2012, connection on 21 September 2020. URL : http://journals.openedition.org/kernos/2055 ; DOI : https://doi.org/10.4000/kernos.2055

This text was automatically generated on 21 September 2020

Kernos 


\title{
Burkhard FEHR, Becoming Good Democrats and Wives. Civic Education and Female Socialization on the Parthenon Frieze
}

\author{
Joannis Mylonopoulos
}

\section{REFERENCES}

Burkhard FEHR, Becoming Good Democrats and Wives. Civic Education and Female Socialization on the Parthenon Frieze, Wien/Zürich/Berlin/Münster, LIT Verlag, 2011. 1 vol. 21,5 × $30 \mathrm{~cm}, \mathrm{XV}+179$ p. (Hephaistos Sonderband). ISBN : 978-3-643-99900-9.

1 The addition of each new book or article on the Parthenon frieze automatically gives rise to the same question: do we really need yet another study on this monument? In my view, the answer is always a clear yes! The Parthenon frieze, a monument that captured and continues to capture the imagination of countless scholars, remains an enigma. The only thing we can be absolutely sure of is its date. Its exact association with Phidias, the number of artists involved in its creation, its political significance - if any - for the citizens of democratic Athens, and above all the precise nature of the topic it represents and how it should be interpreted remain issues much debated. ${ }^{1}$

Burkhard Fehr's monograph focuses on the iconography and iconology of the frieze. Already in the "Foreword" (p. 1-4), the A. claims that the Parthenon frieze aimed "at explicating, systematically and step by step, the guiding principles of the democratic praxis and the values which the Athenian citizens ascribed to the democratic constitution." The assumption that the frieze is in various ways a visual reflection of democratic Athens is obviously not a new one, but F. states that his study will show that the association between the democratic principles and the frieze was methodically 
planned. ${ }^{2}$ Indeed, he argues that this association prevails over any that the frieze may have with religious rites and state festivals.

In the "Introduction" (p. 5-15), F. draws attention to the fact that the young men who occupy the west, north, and south sides of the frieze are generally beardless. Although scholars have noticed this iconographic peculiarity, F. assigns this detail special importance. At this point, he simply expresses his scepticism that the imposition of Archaic ideals - "admirable sons and beautiful horses" as manifestations of "a nobleman's happiness (olbos)" - on democratic Athens can adequately explain the young men's prominence on the frieze. He also briefly touches on the striking female presence on the east part of the frieze. Discussing the notion of schema and ethos, he reveals one of the fundamental ideas on which his interpretation of the entire frieze will rest: "what was most important for the artist conceiving such scenes was the exemplification of patterns of action."

The following three chapters constitute the analytical and interpretive core of the monograph. In Chapter 2 ("The young people of democratic Athens," p.17-81), F. focuses on the human figures that populate the west, north, south, and a large portion of the east frieze. Scholars have unanimously interpreted the scenes on the west frieze as preparations for the cavalcade. The successful taming, bridling, leading, and mounting of the horses were probably meant to display the excellence of Athenian youth. In this context, the nearly identical scenes on slabs W III and XII have proven puzzling: a horse in the centre of the composition, on the left a youth, on the right a boy, and between them a man. Based on three red-figure cups in Berlin and Basle, scholars have identified the scenes in the west frieze as depictions of the dokimasia, the official inspection of the cavalry. According to F., the scenes are not merely depictions of an inspection - official or not - but are also direct invitations to the ancient viewer to evaluate critically both the conduct of the young men and the rebellious nature and unfitting appearance of the horses. Attempting to draw more general conclusions from the iconography of the west frieze, F. maintains that the inspection depicted is simply a pars pro toto for all kinds of inspections that a young male Athenian would undergo before becoming a full member of his polis. Since most of the figures being inspected are beardless young men, F. presupposes an educational background associated both with the concrete dokimasia principle and the general shaping of the Athenian (male)

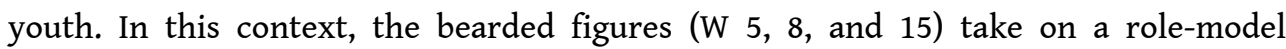
function, which would explain in particular the nearly central and relatively isolated position of $\mathrm{W} 15$. In his view, the didactic quality of the west frieze is additionally revealed by the presence of citizen watchers in the cavalry sections of the south (S 1) and the north ( $\mathrm{N} \mathrm{90)}$ frieze. When it comes to the iconographic details of the young riders not only on the west but also on the north and south sides of the frieze, F. chooses to emphasize not the differences in their attire but the recurring presence of generic young riders. He thus reaches the conclusion that they are an expression of democratic equality, discipline, and collectiveness. Scholars have often proposed arranging the riders on both the north and the south side of the frieze in groups according to the various forms of their attire. ${ }^{3}$ On the contrary, the A. claims that the heterogeneous attributes, garments, and arms of the male youths are merely symbols of the various activities and situations in which the young riders engage. He views the chariots in the depiction of the apobates-race within the context of democratic isonomia, but detects additional emphasis not only on the individual arête of the charioteer and the hoplite but also on the philia that supposedly bound the two. ${ }^{4}$ Although F. accepts 
the traditional view that the majority of the riders and apobatai represent offspring of old aristocratic families, he differs from it in that he recognizes both in the service in the Athenian cavalry and the participation in the apobates-race (as well as the training that it demanded) an opportunity for the city to control aristocratic youth and train it according to the egalitarian principles of democracy. Based on Xenophon's treatise on horsemanship, F. suggests that the perfect schemata of the horses on the Parthenon frieze can be seen as visual metaphors for the successful education of young Athenians by their polis. In short, the western part of the frieze as well as those sections of the north and south sides that depict riders or chariots symbolize the stages of examination, disciplined participation, and expression of arête as well as philia in a competitive arena. Conversely, F. regards those segments of the north, south, and east sides that depict pedestrians in a procession as a manifestation of sophrosyne. Although he does not seem to deny the clearly sacral nature of the scene, he prefers to approach these parts of the frieze from the perspective of democratic values. For this reason, he rejects the identification of the bearded figures (N 37-43) as thallophoroi and instead sees them as symbols of "the meritorious older generation of Athenian citizens." The ends of the south and north parts of the frieze thus bring together the younger and the older generations of Athenian citizens. Admittedly, the status (married women or parthenoi) of the female figures on the east frieze continues to be a matter of scholarly debate, and F. suggests seeing all of them (E 2-17, 50-51, 53-63) as young parthenoi, the equivalents of the beardless young men in the rest of the frieze.

In Chapter 3 ("The heroized ancestors of the Athenian citizens," p. 83-91), F. briefly discusses ten figures of the east frieze (E 18-23, 43-49) that are usually identified as representations of the ten eponymous heroes of the Cleisthenic phylai. F. does not reject the heroic status of these figures, but he chooses to see them as general representations of the divine race of (Athenian) heroes in the Hesiodic sense rather than as depictions of concrete heroic figures. Thus in very general terms, the ten male figures are the heroic ancestors and role models of the Athenians. Chapter 4 ("Deities, polis and oikos," p. 93-119) discusses the very centre of the east frieze with the divine assembly and the five-figure scene directly above the temple's main entrance. According to F., the divine pairs in the left half of the assembly (Hermes, Dionysos, Demeter, Ares, Hera, and Zeus) represent various aspects of fertility as well as the notion that war (Ares) can protect the agricultural wealth and human offspring of a city. Especially intriguing is F.'s interpretation of the torch in Demeter's left hand, which iconographically ties her to Ares, since according to an ancient scholion, in times of war priests of this god walked before armies holding torches and gave the battle signal by throwing them into the enemy's ranks. The divine pairs on the right half represent the principles of social balance as exemplified by the respectful relations between older and younger members of society (Poseidon - Apollon, Aphrodite Artemis) as well as the harmonious ties among equals (Athena - Hephaistos). In my view, the pairings of the gods in the frieze represent something concretely Athenian rather than some generic notion of fertility and proper social conduct. In the central scene above the entrance into the pronaos, F. recognizes a representation of the ideal Athenian oikos, whose members are involved in some kind of cultic activity that by no means is the centre of attention. F. likewise rejects the idea that the ritual referred to here has anything to do with the Panathenaic festival. Figures E 31-33 depict the female members of the family with a mother (E 33) instructing her daughters who carry wool offerings to a deity. Accordingly, he interprets figures E 34 and 35 as symbols of the 
male sector of an oikos with a father (E 34) dressed as a priest educating his young son (E 35). Thus the cloth in the hands of E 34 and 35 is not Athena's peplos, but the older man's own himation, which he has just taken off. Like many scholars before him, F. dismisses the notion that $\mathrm{E} 35$ is a girl due to the figure's partial nudity, a feature that goes "beyond the limits prescribed by the iconographic rules of the $5^{\text {th }}$ century for the representation of well-educated girls and women." ${ }^{5}$ In general, F. interprets the culmination of the entire frieze as an anonymous domestic scene symbolizing "the correct behavior of the members of the domestic communities in democratic Athens." In the final part of this chapter, F. constructs rather complicated interconnections between a) the parthenoi in the procession and their alleged married counterpart, figure E 33, b) Eros and Hebe and the parthenoi, c) figures E 33 and 34 as ideal members of a representative Athenian couple and Athena and Hephaistos the "divine paradigms for the allocation of gender roles" in Athenian society.

6 In the very brief fifth chapter ("A retrospective look at the frieze," p. 121-122), F. repeats that the frieze functioned as a visualization of the city's good fortune because members of the Athenian society followed the divine principles embodied by the gods on the east frieze. According to F., the fundamental message conveyed by the frieze is the interdependence of polis (west, north, south, and a large portion of the east sides) and oikos (central scene of the east side).

7 In Chapter 6 ("The frieze and the Parthenos in the Parthenon," p. 123-133), F. claims a link between the female aspects of the east frieze and the iconography of the chryselephantine statue of Athena Parthenos. He claims, in fact, that all the iconographic elements of the statue, such as the deity's rich jewellery, her magnificent garment, the base depicting the myth of Pandora, the Centauromachy carved on her sandals, the Amazonomachy on the outer side of her shield, the Nike statue in her outstretched right hand, and the snake at her side emphasize the goddesses' feminine qualities and her role as educator of young Athenian women. F. views even the Gigantomachy on the inner side of Athena's shield as a visual reference to the fate of a woman (Gaia) who revolts against the divine order. F.'s interpretation of the statue as the embodiment of the principles of female behaviour appears rather one-sided. - In Chapter 7 ("The frieze and the other Parthenon sculptures," p. 135-139), F. interprets the rest of the temple's sculptural decoration in the same spirit. Thus the western pediment symbolizes Athens' faith in nomoi and justice, while the eastern one makes a divine analogy to the functioning civic community of Athens. Accordingly, F. reads the metopes as symbolic representations of threats to the oikos (Centauromachy, Trojan War), the divine order and its protection as a model for human societies (Gigantomachy), and the fate of women who overstep social and gender boundaries (Amazonomachy). - In the final chapter ("Political background," p. 141-144), F. interprets the sculptural programme of the Parthenon, especially the frieze, and the chryselephantine statue in light of political developments of the late sixth and fifth centuries BCE. He lays special emphasis on the citizenship law of 451/50 BCE and suggests that both the east frieze and the statue of Athena were meant to grant visual form to the superiority of Athenian women and at the same time address "the role and function of the citizens' women." He also claims that the splendid male youths in the rest of the frieze would have led viewers to conclude that only "wives who were worthy of their Athenian husbands" could give birth to such offspring. 
In his synopsis (p. 145-149), F. summarizes his main thesis that both the architectural sculpture of the Parthenon and the chryselephantine statue portray the education and socialization processes of Athenian male and female youth in accordance not only with the divine order but also the principles of democracy. In addition, he insists that the interpretation of the frieze as a reference to the Panathenaic festival should be completely abandoned. - In the epilogue (p.151-154), he presents the frieze more generally as the "first comprehensive discourse on democracy." His brief discussion of the ambivalent nature of Athenian democracy/imperialism remains too vague to be helpful for comprehending the monument.

The volume concludes with a bibliography (p. 155-169) - note that two works by J. Neils have been scrambled together on page 163 - and a useful index (p. 171-179).

Although the idea that a monument and its decoration served a didactic purpose inter alia is not truly new, the almost radical way in which F. applies this approach to the interpretation of the Parthenon frieze is. However, this is partly the problem, since in order to make all of the iconographic details fit into his reading of the monument, F.'s interpretations tend at times to become so general/generic that they could be applied to many monuments, and not only to Athenian ones. In addition, I am not convinced by his argument that there is no connection between the frieze and the Panathenaic festival, and that the plethora of visual references to cult vessels and other paraphernalia, the presence of sacrificial animals, the ceremonial course of the pedestrians towards the culmination of the frieze on the east side, and so many other details are all secondary elements that merely underscore a depiction of exemplary behaviour and democratic social interaction. In general, I find rather implausible the idea that an entire temple with an extremely ambitious sculptural programme and a statue that surpassed all earlier and later depictions of Athena was created as a manual for and portrayal of the education and socialization of Athenian youth. Nonetheless, I derived much profit from reading this intellectually provocative and erudite volume that continuously challenges the reader to rethink a monument still not fully understood. Indeed, I find myself looking forward to the next monograph on the Parthenon frieze.

\section{NOTES}

1. Even though most scholars favour some kind of association with the Panathenaic festival, they disagree over the exact nature of this connection (literal, metaphorical, symbolic). For a helpful overview of the most prominent interpretations of the frieze, see J. NEILS, The Parthenon Frieze, Cambridge, 2001, p. 173-186.

2. H. VON WREDE, Das Lob der Demokratie am Parthenonfries, Mainz, 2008 is a study with a similar, nearly identical starting point, which, however, came too late to the attention of the A. to be fully considered. Nonetheless, von Wrede accepts the connection of the frieze with the Panathenaic festival, which F. dismisses. 
3. See recently, T. OSADA, "Also 10 Tribal Units: The Grouping of Cavalry on the Parthenon North Frieze," AJA 115 (2011), p. 537-548.

4. For a recent nuanced interpretation of the leading apobates on the north frieze (N 47), see J. NEILS, P. SCHULTZ, "Erechtheus and the Apobates Race on the Parthenon Frieze (North XI-XII)," AJA 116 (2012), p. 195-207.

5. One needs to ask whether the representations of naked girls on krateriskoi associated with the Attic cults of Artemis Brauronia and Mounichia or the representation of Kassandra completely nude in the context of her rape by Ajax on Athenian red-figure vases are following a different set of "iconographic rules."

\section{AUTHORS}

\section{JOANNIS MYLONOPOULOS}

Columbia University - New York 